\title{
PENANAMAN SEMANGAT NASIONALISME PADA SISWA (Studi pada SMP Negeri di Kabupaten Jeneponto)
}

\author{
Oleh; \\ SUKRI BADARUDDIN \\ Sekolah Tinggi Agama Islam Negeri (STAIN) Majene \\ e-mal: sukribadaruddin@stainmajene.ac.id
}

\begin{abstract}
ABSTRAK: Rumusan masalah yang dikaji dalam penelitian ini (1) Bagaimana bentukbentuk pembinaan penanaman prinsip-prinsip nasionalisme bagi siswa pada SMP Negeri di Kabupaten Jeneponto (2) Bagiamana hambatan penanaman sikap nasionalisme bagi siswa pada SMP Negeri di Kabupaten Jeneponto (3) Bagaimana Upaya yang dilakukan sekolah dalam meningkatkan nasionalisme siswa pada SMP Negeri di Kabupaten Jeneponto. Tujuan penelitian ini adalah (1) untuk mengetahui Bentuk-bentuk pembinaan penanaman prinsip-prinsip nasionalisme bagi siswa pada SMP Negeri di Kabupaten Jeneponto (2) Hambatan penanaman sikap nasionalisme bagi siswa pada SMP Negeri di Kabupaten Jeneponto (3) Upaya yang dilakukan sekolah dalam meningkatkan nasionalisme siswa SMP Negeri di Kabupaten Jeneponto. Penelitian Ini menggunakan pendekatan/metode deskriptif kualitatif, dengan teknik pengumpulan data, observasi, koesioner, wawancara dan fokus group discusssion. Hasil penelitian menunjukkan bahwa (1) Proses pembinaan semangat nasionalisme perlu dilakukan supaya identitas siswa sebagai warga negara Indonesia tidak menghilang yaitu dengan mengintegrasikan prinsip yang terkandung dalam nasionalisme seperti (a) prinsip kebersamaan yang menuntut setiap warga negara untuk menempatkan kepentingan bangsa dan negara di atas kepentingan pribadi dan golongan, (b) prinsip persatuan dan kesatuan yaitu warga negara harus mampu mengesampingkan kepentingan pribadi atau golongan yang dapat menimbulkan perpecahan dan anarkis (merusak), (c) prinsip demokrasi/demokratis memandang bahwa setiap warga negara mempunyai kedudukan, hak, dan kewajiban yang sama. (2) Hambatan yang dihadapi oleh guru Pendidikan Kewarganegaraan yaitu nasionalisme tidak memiliki materi tersendiri sehingga menyebabkan guru hanya bisa menyisipkan materi disela-sela pelajaran dan Program Sekolah dalam pembinaan semangat nasionalisme siswa masih menghadapi hambatan atau kendala dalam proses pembinaannya bagi siswa. Disadari bahwa kultur masyarakat kita yang beragam dan masih minimnya kegiatan yang berkaitan tentang nasionalisme dalam mendukung terlaksananya kegiatan pembinaan siswa yang dilakukan sekolah serta masih terbatasnya peranan pemerintah dalam membina semangat nasionalisme peserta didik. (3) Upaya yang dilakukan sekolah dalam penanaman naisonalisme yaitu memperingati hari-hari nasional seperti ikut dalam peserta setiap 17 Agustus dan hari-hari nasional lainnya serta pengaktifan organisasi intra dengan ekstrakurikuler.
\end{abstract}

\section{KATA KUNCI: Penanaman Nasionalisme, Siswa}

ABSTRACT: The formulated problems examined in this study are (1) What forms of fostering the investment of nationalism principles for students in State Junior High Schools in Jeneponto are (2) What challenges to investing nationalism behaviour for students in State Junior High Schools in Jeneponto are (3) What efforts are made by the school in fostering students' nationalism in state junior high schools in Jeneponto. The aims of the study are (1) to find out the fostering forms of national principle 
encouragement for students in state junior high schools in Jeneponto (2) to establish the challenges to investing nationalism behaviour for students in state junior high schools in Jeneponto (3) to describe the efforts made by the school in fostering students' nasionalism in state junior high schools students in Jeneponto. This study employs a descriptive qualitative approach with data collection methods; observation, questionnaire, interview and focused group discussion. The results of the study show that (1) the process of fostering the spirit of nationalism needs to be carried out, so the student's identity as an Indonesian still exists by integrating the principles included in nationalism, such as (a) the principle of togetherness that demands every citizen to place the national and state interests above the individual and group interests, (b) the principle of unity in which citizens must be able to set aside personal or group interests that can lead to disunity and anarchism, (c) the principle of democracy which regards that every citizen has an equal position, rights, and obligations. (2) Challenges encountered by the teachers are that there is no specific materials pertaining to nationalism, so the teachers are only able to provide the materials on the sidelines of the lesson and that the School Program in fostering the spirit of students' nationalism still encounters some constraints in its guding process towards students. It is realized that the culture of our society is diverse, the lack of activities related to nationalism in supporting the implementation of student coaching activities undertaken by schools is obvious, and the role of government in fostering the spirit of student's nationalism is still limited. (3) Efforts made by schools in fostering nationalism are to commemorate national days, like participating in activities both on independence day and on other national days, and activating intra-extracurricular organizations.

KEYWORDS: Fostering Nationalism, Students

\section{PENDAHULUAN}

Bangsa Indonesia merupakan bangsa yang majemuk yang terdiri dari berbagai suku, etnis, bahasa , agama dan lain-lain. Maka dari itu prinsip yang dianut oleh bangsa Indonesia sebagai negara Bhineka Tunggal Ika yang mencerminkan berbagai suku, etnis bahasa dan kebudayaan namun tetap terintegrasi oleh keikatan dan kesatuan. Ajaran tentang kebangsaan sebagai suatu cara memperoleh kemerdekaan memperoleh landasan kultural yang mendalam. Sehingga pembagunan maupun kemerdekaan itu pun merupakan bagian dari kebudayaan sebagai perjuangan. Kebudayaan itu mempersatukan dan tidak memecah bela.
Namun pelestarian kebudayaan Indonesia sangat lemah sedangkan pertumbuhann peradaban dan kebudayaan global berkembang sangat cepat.

Untuk dapat mengimbangi kebudayaan global diperlukan rasa kebanggaan identitas nasional, rasa kebangsaan ini melahirkan sikap nasionalisme. Undang-Undang Dasar 1945 pasal 27 ayat (3) yaitu: Setiap warga negara berhak dan wajib ikut serta dalam upaya pembelaan negara ${ }^{1}$. Keikutsertaan warga negara dalam bela negara dibagi dua yaitu fisik dan non fisik. Dalam Undang-Undang Nomor 3 Tahun 2002 tentang Pertahanan Negara pasal 9 ayat (2) point b dan c ditegaskan bela negara secara fisik yaitu: keikutsertaan warga negara dalam upaya bela negara,

\footnotetext{
1 Undang-Undang Dasar Negara Republik Indonesia Tahun 1945 pasal 27 ayat 3.
} 
sebagaimana dimaksud dalam ayat (1), diselenggarakan melalui: (a) pendidikan kewarganegaraan; (b) pelatihan dasar kemiliteran secara wajib; (c) pengabdian sebagai prajurit tentara nasional indonesia secara sukarela atau secara wajib ; dan (d) pengabdian sesuai dengan profesi ${ }^{2}$. Bela Negara secara nonfisik dilakukan dalam berbagai bentuk dan dilakukan sepanjang masa di antaranya: (a) meningkatkan kesadaran berbangsa dan bernegara termasuk menghayati arti demokrasi dengan menghargai perbedaan pendapat dan tidak memaksakan kehendak. (b) menanamkan kecintaan terhadap tanah air melalui pengabdian yang tulus kepada masyarakat; berperan aktif dalam memajukan bangsa dan negara dalam berkarya nyata (bukan retorika). (c) meningkatkan kesadaran dan kepatuhan terhadap hukum/undangundang dan menjunjung tinggi hak asasi manusia. (d) pembekalan mental spiritual dikalangan masyarakat agar dapat menangkal pengaruh-pengaruh budaya asing yang tidak sesuai dengan normanorma kehidupan bangsa Indonesia dengan lebih bertakwa kepada Allah SWT. Melalui agama/kepercayaan masing-masing. ${ }^{3}$

Nasionalisme itu sangat penting bagi persatuan bangsa hal ini tertuang dalam pancasila sila ke-3 persatuan Indonesia dimana dijelaskan bahwa nilai persatuan Indonesia mengandung makna usaha kearah bersatu dalam kebulatan rakyat untuk membina rasa nasionalisme dalam Negara Kesatuan Republik Indonesia. Persatuan Indonesia sekaligus mengakui dan menghargai sepenuhnya terhadap keanekaragaman yang dimiliki

\footnotetext{
${ }^{2}$ Undang-Undang Nomor 3 Tahun 2002 tentang Pertahanan Negara pasal 9 ayat $1,2 \& 3$.

${ }^{3}$ Wandhi Pratama Putra Sisman \& Rauf, Ruslan. 2016."Pendidikan Kewarganegaraan Bingkai NKRI'. Jakarta, Mitra Wacana Media, Hal. 279

4 ibid. 2016:8-9.
}

bangsa Indonesia. Adanya perbedaan bukan sebagai sebab perselisihan tetapi justru dapat menciptakan kebersamaan. ${ }^{4}$ Nasionalisme membangun kesadaran rakyat sebagai suatu bangsa serta memberi seperangkat dan program tindakan. Sebagai generasi penerus yang harus yang dilakukan adalah bagaimana caranya untuk mengisi kemerdekaan ini dan salah satunya dengan pembagunan nasional. Nasionalisme dapat dijadikan sebagai dasar pembangunan Negara Kesatuan Republik Indonesia. Paham nasionalisme merupakan sebuah kejiwaan dimana kesetiaan seseorang secara total diabdikan langsung kepada negara bangsa atas nama seluruh bangsa. Munculnya nasionalisme terbukti sangat efektit sebagai alat perjuangan bersama merebut kemerdekaan dari cengkeraman kolonialisme ${ }^{5}$. Ir. Soekarno dalam pidatonya didepan sidang Umum PBB dengan memfokuskan kepada kata nasionalisme. ${ }^{6}$ Nasionalisme ini merupakan kekuatan yang dapat membakar dan menimbulkan hasrat untuk kemerdekaan. Dengan nasionalisme ini bangsa Indonesia dapat mempertahankan hidupnya, memberi kekuatan sepanjang kegelapan penjajahan yang lama dan selama berkobarnya perjuangan kemerdekaan. Dewasa ini kekuatan yang membakar itu masih tetap menyalah-nyalah di dada bangsa Indonesia dan tetap memberi kekuatan hidup bangsa. Nasionalisme merupakan perpaduan atau sinergi dari rasa kebangsaan dan paham kebangsaan. Kondisi nasioanalisme suatu bangsa akan terpancar dari kualitas dan ketangguhan bangsa tersebut dalam menghadapi

\footnotetext{
${ }^{5}$ Syarbaini, Syahrial dkk. 2006. "Membangun Karakter dan Kepribadian melalui Pendidikan Kewarganegaraan”. Yogyakarta: Graha Ilmu, Hal. 46.

'Saksono, Gatut. 2007. "Pancasila Soekarno”. Yogyakarta: Urna Cipta Media Jaya.PT Raja Grafindo Persada, Hal. 78.
} 
berbagai ancaman. Nasionalisme yang tinggi, kekhawatiran akan terjadinya ancaman terhadap keutuhan dan kesatuan bangsa akan dapat di elakkan. Dari nasionalisme akan mengalir rasa kesetiakawanan sosial, semangat rela berkorban dan menumbuhkan jiwa patriotisme.Nasionalisme bangsa Indonesia merupakan perwujudan rasa cinta bangsa Indonesia terhadap negara dan tanah air berdasarkan pancasila. Namun yang terjadi saat ini justru sebaliknya, nasionalisme terkikis perlahan dan di gantikan paham baru. Kekhawatiran akan merosotnya nasionalisme dan terjadinya disintegrasi nasional cenderung meningkat akhirakhir ini. Sebagai kekuatan dasar dalam berbangsa dan bernegara, nasionalisme sedang diuji fleksibelitasnya dalam arti kemampuan untuk berubah sehingga selalu dinamis dalam menjawab tantangan zaman. Karena terkikisnya nasionalisme inilah banyak pihak yang mulai membangkitkan semangat nasionalisme melalui berbagai kegiatan. Sikap nasionalisme atau cinta tanah air ini harus dimiliki oleh setiap penduduk serta bangsa di dunia ini. Hal ini dikarenakan pentingya sikap nasionalisme dalam menjaga keutuhan suatu bangsa. Begitu pula halnya dengan Indonesia, setiap warganya harus memiliki sikap nasionalisme sebagai salah satu cara untuk menjaga keutuhan Negara Republik Indonesia (NKRI). Peran serta pemuda khususnya pelajar sebagai generasi penerus sangatlah penting dalam menjaga keutuhan NKRI karena di pundak generasi muda masa depan bangsa digantungkan. Mempertahankan dan membela negara merupakan tugas bagi setiap warga negara indonesia tidak terkecuali para genersi muda khususnya pelajar sebagai generasi penerus yang ikut menentukan nasib bangsa ini. Untuk mengembang tugas tersebut setiap warga perlu memiliki pemahaman dan jiwa nasioalisme sebagai dasarnya. Generasi muda dalam hal ini pelajar khususnya juga harus memiliki jiwa dan semangat nasionalisme yang membara didalam dirinya. Secara umum nasionalisme pelajar kini dinilai kurang dan mulai luntur terkikis seiring perkembagan zaman. Hal ini terlihat dari anak-anak lebih menyukai dan bangga dengan budaya asing daripada budaya asli bangsanya sendiri dan merasa bangga manakala menggunakan produk luar negeri, dibandingkan jika menggunakan produk bangsa sendiri. Berdasarkan observasi, penulis berpandangan bahwa semangat nilai nasionalisme pada generasi bangsa sekarang ini mengalami dekadensi nasionalisme, itu dapat dilihat dari kurangnya penghayatan anak di zaman sekarang ini ketika upacara bendera, beberapa anak dalam lingkup sekolah tidak hafal lagu-lagu nasional maupun lagu daerah, tidak mengetahui nama-nama pahlawan nasional, bahkan ada juga beberapa anak tidak hafal silasila pancasila dan UUD NRI Tahun 1945. Hal ini juga menunjukan adanya kemorosotan rasa nasionalisme sebagai pijakan teguh kepribadian bangsa telah hilang dan luntur seiring dengan perkembangan zaman.

\section{NASIONALISME}

Sebelum paham nasionalisme muncul, telah ada paham kosmopolis, yakni, paham yang mengajarkan bahwa manusia bukan warga sesuatu negara, tetapi warga dunia. Tanah air setiap manusia adalah dunia seluruhnya. Sebagai bukti misalnya tercermin dalam imperium Romawi yang berdiri tidak berdasarkan bangsa Romawi, tetapi atas keperkasaan tentara romawi dan hukum romawi yang meliputi hampir seluruh bangsa pada waktu itu. Kemudian beriringan dengan kemajuan zaman dan dinamika kebangsaan melalui fase 
reformasi dan pencerahan, perlahan tapi pasti paham kosmopolis memudar dan mulai digantikan oleh paham nasionalisme. Sehingga realitas sejarah menunjukkan, sejak akhir abab ke-18 sampai abab ke-20 paham nasionalisme sudah dianut oleh hampir seluruh negara di dunia ini.

Akibat dari terbentuknya negara adalah lahirnya nasionalisme dari rakyatnya. Nasionalisme berasal dari kata nation yang berarti bangsa. Menurut kamus besar bahasa Indonesia nasionalisme berarti: (1) Paham (ajaran) untuk mencintai bangsa dan negara sendiri; sifat kenasionalan. (2) Kesadaran keanggotaan dalam suatu bangsa yang secara potensial atau aktual bersamasama mencapai, mempertahankan dan mengabdikan identitas, integritas, kemakmuran dan kekuatan bangsa itu; semangat kebangsaan.

Nasionalisme merupakan sebuah penemuan sosial yang paling menakjubkan dalam perjalanan sejarah manusia, paling tidak seratus tahun terakhir. Tidak ada satu pun ruang sosial di muka bumi lepas dari pengaruh ideologi ini. Tanpa nasionalisme, lajur sejarah manusia akan berbeda sama sekali. Berakhirnya perang dingin dan semakin merebaknya gagasan dan budaya globalisme (internasionalisme) pada dekade 1990-an hingga sekarang, khususnya dengan adanya teknologi komunikasi dan informasi yang berkembang dengan sangat pesat. Nasionalisme yang melahirkan bangsa berada di titik persinggungan antara politik teknologi dan transformasi sosial.

Paham nasionalisme atau paham kebangsaan adalah sebuah situasi

7 Syarbaini, Syahrial M.A. 2011. "Pendidikan Pancasila (Implementasi Nilai-Nilai Karakter Bangsa) Diperguruan Tinggi”. Ghalia Indonesia, Hal. 201. kejiwaan dimana kesetiaan seseorang secara total diabdikan lansung kepada negara bangsa atas nama sebuah bangsa. Munculnya nasionalisme terbukti sangat efektif sebagai alat perjuangan bersama merebut kemerdekaan dari cengkeraman kolonial. (Syarbaini, :201;20117). Nasionalisme disini adalah suatu paham yang menganggap bahwa kesetiaan tertinggi bagi setiap pribadi (individu) harus di serahkan kepada negara kebangsaan. Sedangkan dalam kamus politik, nasionalisme adalah perasaan atas dasar kesamaan asal-usul rasa kekeluargaan, rasa memiliki hubungan yang lebih erat dengan sekelompok orang daripada dengan orang-orang lain dan mempunyai perasaan berada dibawah satu kekuasaan. Nasionalisme di perkuat dengan adanya dongeng-dongeng dan mitos-mitos, serta oleh satu bahasa yang sama; semangat kebangsaan ${ }^{8}$.

\section{Hakikat Nilai}

Terdapat banyak pandangan tentang nilai dan hal ini sangat menentukan tentang hierarki nilai. Misalnya kalangan materialis memandang bahwa nilai tertinggi adalah nilai material, kalangan hedonis berpandangan bahwa nilai yang tertinggi adalah nilai kenikmatan. Pada hakikatnya segala sesuatu itu bernilai hanya nilai apa yang ada serta hubungan nilai serta penggolongannya sangat beraneka ragam. Max Scheler mengemukakan bahwa nilai-nilai yang ada, tidak sama luhurnya dan sama tingginya. Nilai-nilai secara nyata ada yang lebih tinggi dan ada yang lebih rendah dibandingkan dengan nilai-nilai lainnya. ${ }^{9}$

\footnotetext{
${ }^{8}$ Gatara FH Asep Sahid \& Sofhian, Subhan. 2012. "Pendidikan Pancasila (Civic Education)”. Fokusmedia, Hal. 17-18.

${ }^{9}$ M Daryono, dkk .1997."Pengantar Pendidikan Pancasila dan Kewarganegaraan" Jakarta Timur: Rineka Cipta, Hal. 20.
} 


\section{Pendekatan dan Strategi Penanaman Nilai}

Berbagai nilai yang sudah ada tersebut perlu dan penting untuk dikembangkan semaksimal mungkin. Munculnya nilai dikarenakan adanya dorongan dari dalam diri manusia, diantaranya adalah dorongan untuk memenuhi kebutuhan fisik untuk kelangsungan hidupnya, kebutuhan akan rasa aman, kebutuhan akan rasa cinta kasih, kebutuhan akan penghargaan dan dikenal orang lain, kebutuhan akan pengetahuan dan pemahaman, kebutuhan akan keindahan dan aktualitas diri.

Setiap guru (pendidik) menpunyai tugas dan kewajiban yang sama untuk menanamkan nilai-nilai insaniyah dan nilai ilahiyah terhadap anak didik. Kiranya perlu meretas batas domain dalam sistem teknologi instruksional sehingga setiap bidang studi secara integral memuat wawasan nilai, ilmu dan kompetensi. Untuk membentuk pribadi yang memiliki nilai/moral yang baik maka diperlukan adanya suatu pendekatan penanaman nilai (inculcation approach) yaitu suatu pendekatan yang memberi penekanan pada penanaman nilai sosial dalam diri siswa pada khususnya dan masyarakat pada umumnya. Pendekatan penanaman nilai ini memiliki dua tujuan yaitu pertama diterimanya nilai-nilai sosial tertentu oleh peserta didik, kedua berubahnya nilainilai peserta didik yang tidak sesuai dengan nilai-nilai sosial yang diinginkan mengarahkan pada perubahan yang lebih baik.

\section{Bentuk-Bentuk Nasionalisme}

Beberapa bentuk nasionalisme dan gerakannya yang terjadi di Indonesia adalah: (a) Nasionalisme Kemandirian Bangsa, dimana semangat bernegara di

10 Budiyono, Kabul. 2007. "Nilai-Nilai Kepribadian dan Kejuangan Bangsa bangun untuk mewujudkan kejayaan bangsanya, contoh: Zaman Sriwijaya, Majapahit dan Samudra Pasai. (b) Nasionalisme Agama, yaitu gerakan yang berupaya menperoleh kemerdekaan melalui semangat keagamaan, contoh: upaya yang diplopori oleh Serikat Islam (SI) sejak tahun 1911 dalam melawan kolonilisme Belanda. (c) Nasionalisme Sekuler, gerakan yang memperoleh kemerdekaan dengan tidak menyebutkan agama sebagai inspirasi gerakan walaupun tidak menentang adanya peran agama dalam kegiatan politik, contok gerakan yang dilakukan oleh Soekarno tahun 1927 melalui partai nasional Indonesia. (c) Nasionalisme Anti Agama (komunis) sebenarnya cirri nasionalisme ini lebih mengarah pada internasionalisme, berbeda dengan bentuk gerakan kedua yang menjadikan agama sebagai spirit gerakannya, nasionalisme anti agama tidak memberikan peran agama bahkan agama tidak berperan dalam gerakan dan harus dijauhi ${ }^{10}$

\section{METODE PENELITIAN}

Pendekatan yang digunakan dalam penelitian ini adalah pendekatan kualitatif. Pendekatan kualitatif merupakan pendekatan yang bertujuan memberi gambaran dan penjelasan yang ilmiah terhadap obyek yang akan diteliti. Alasan peneliti ini menggunakan pendekatan kualitatif karena dalam penelitian ini sebagai bagian dari metode deskriptif, dengan memahami mengapa suatu gejala terjadi atau sebab suatu peristiwa menggambarkan fakta untuk memperjelas begaimana keadaan suatu gejala, suatu peristiwa, atau keadaan dari obyek yang sedang diselidiki.

Indonesia”. Bandung: Alfabeta, Hal. 209-210. 
Penelitian ini bertujuan untuk mengetahui: 1) Bentuk-bentuk pembinaan penanaman prinsip-prinsip nasionalisme yang dilakukan Institusi Pendidikan pada Jenjang SMP Negeri di Kabupaten Jeneponto 2) Hambatan penanaman sikap nasionalisme bagi siswa SMP Negeri wilayah Dinas Pendidikan di Kabupaten Jeneponto (3) Upaya yang dilakukan sekolah dalam meningkatkan nasionalisme siswa SMP Negeri di Kabupaten Jeneponto

Untuk mencapai tujuan tersebut maka peneliti menggunakan pendekatan deskriptif kualitatif, jenis penelitian kualitatif, sumber data primer yaitu informan anatara lain yaitu Kepala Dinas Pendidikan, Guru PKn di SMP Negeri di Kabupaten Jeneponto dan data sekunder yaitu dokumen, buku, jurnal, dan perundang-undangan. Teknik pengumpulan data yang digunakan yaitu observasi, wawancara, dan dokumentasi, Teknik analisis data yang digunakan adalah deskriptif kualitatif.

\section{HASIL DAN PEMBAHASAN}

\section{Penanaman Nasionalisme}

\section{Prinsip-prinsip}

Pendidikan yang masih rendah tentu akan berpengaruh terhadap tingkat pemahaman dan partisipasinya terhadap warga negara yang baik, untuk dapat berpartisipasi secara bermutu dan bertanggung jawab warganegaraan memerlukan penguasaan sejumlah kompetensi, diantaranya yang terpenting adalah penguasaan terhadap pengetahuan dan pemahaman tertentu serta komitmen yang benar terhadap nilai-nilai prinsip dasar demokrasi konstitusional.

Nasionalisme adalah salah satu sikap yang harus dimiliki oleh setiap siswa/mahasiswa dan guru/dosen adalah orang yang harus bisa memberikan pemahaman kepada siswa/mahasiswa tentang apa itu nasionalisme. Nasionalisme sendiri adalah bela negara secara pasif sebagaimana termaktub dalam Undang-Undang Dasar 1945 pasal 27 ayat (3) yaitu: Setiap warga negara berhak dan wajib ikut serta dalam upaya pembelaan negara. Keikutsertaan warga negara dalam bela negara dibagi dua yaitu fisik dan non fisik.

\section{Prinsip Kebersamaan}

Sikap kebersamaan menuntut setiap warga negara untuk menempatkan kepentingan bangsa dan golongan diatas kepentingan bangsa dan golongan. Penerapan prinsip ini dalam kehidupan sehari-hari menuntut warga negara agar memiliki sikap pengendalian diri dalam kehidupan nasional yang mencakup kehidupan politik, ekonomi, sosial budaya pertahanan keamanan harus tercermin dalam pola pikir, pola sikap, serta pola tindak. Budaya gotong royong, kesediaan untuk saling menghargai dan saling menghormati perbedaan, serta kerelaan berkorban untuk kepentingan bangsa yang harus melekat kuat dalam sanubari setiap warga negara.

\section{Prinsip Persatuan dan Kesatuan}

Persatuan dan kesatuan mengandung arti bersatunya bermacam macam corak yang beraneka ragam menjadi satu kebulatan yang utuh dan serasi. Seluruh rakyat yang merasa senasib dan sepenanggungan yang bermukin didalam wilayah telah berhasil menjadi bangsa yang merdeka dan membentuk negara kesatuan yaitu Negara Kesatuan Republik Indonesia (NKRI).

Indonesia tidak hanya sebuah negara yang memiliki aneka suku bangsa, bahasa tapi juga agama. Oleh karena itu isu yang menyangkut SARA merupakan hal yang sangat sensitif. Persatuan dan kesatuan sendiri berasal dari kata satu yang berarti utuh atau tidak terpecah- 
belah. Materi tentang cinta tanah air, patriotisme, bela negara dan pancasila sangat erat kaitannya dengan nasionalisme Indonesia.

Semangat nasionalisme tidak menghilang dan tetap bertahan dijiwa warga negara maka perlu membangun kembali warga negara yang memiliki nilai-nilai karakter dan kepribadian bangsa yang kuat, memiliki pemahaman, penghayatan dan kesadaran yang tinggi akan hak dan kewajiban sebagai warga negara, mampu dan cakap melaksanakannya dalam kehidupan sehari-hari disegvala bidang kehidupan dengan dilandasi oleh prinsip proporsionalistas, nilai-nlai spiritualitas, keagamaan, nilai-nilai pluralitas sosialbudaya, nasionalisme kultural, nilai-nilai persatuan dan kesatuan bangsa.

Upaya institusi pendidikan dalam menumbuhkan rasa persatuan dan kesatuan menurut hemat penulis bahwa persatuan sangatlah penting bagi sebuah bangsa yang ingin hidup sejahtera sehingga berdasarkan observasi penulis di beberapa institusi pendidikan melaksanakan kegiatan jumat bersih dimana pelajar di ajarkan untuk saling membantu dalam membersikan, gotongroyong

Nasionalisme Indonesia saat ini terancam dan sedang mengalami krisis demokrasi, moral, sosial dan politik karena tujuan demokrasi belum terwujud. Dalam situasi dan kondisi dimana demokrasi berkombinasi dengan krisis yang rentang konflik horizontal dan pertarungan kekuasaan antar elite politik baik yang berkedudukan dilembaga legislatif maupun eksekutif, semakin menyeret kehidupan berbangsa dan bernegara kekalutan, ketegangan dan krisis berkepanjangan. Bila proses transisi ini tidak kita lalui dengan baik kita menghadapi ancaman disintegrasi sosial yang pada gilirannya akan manghancurkan nasionalisme.
Hal ini penulis mengungkapkan bahwa pelajar (siswa/mahasiswa) diajarkan untuk saling menghargai pendapat orang lain, bersedia bergaul dengan teman sekolah tanpa membeda bedakan, menerima teman-teman yang berbeda latar belakang budaya, ras, dan agama, menghargai pendapat teman meskipun pendapat itu berbeda dengan kita. Hal ini dapat dilihat dari kegiatan diskusi pelajar yang di ajarkan untuk menghargai pendapat orang lain, mengutamakan musyawarah, membuat kesepakatan untuk menyelesaikan masalah, sikap anti terhadap kekerasan dan berpartisipasi dalam kegiatan disekolah baik belajar maupun organisasi.

Upaya Institusi pendidikan dalam penanaman sikap demokrasi disekolah mauun di Perguruan Tinggi menurut hemat penulis yaitu pengembangan sikap demokrasi dalam pembentukan mental peserta didik sesuai nilai-nilai demokrasi, sekolah ataupun perguruan tinggi juga mencakup proses pembelajaran untuk meningkatkan kualitas hasil belajar. Tumbuhnya semangat persaudaraan antara siswa/mahasiswa dan guru/doesn harus menjadi iklim pembelajaran di kelas dalam mata pelajaran/mata kuliah apapun. Interaksi guru/dosen (pendidik) dan siswa/mahasiswa bukan sebagai subjek maupun objek, melainkan subjekataupun objek yang sama-sama membangun karakter dan jati diri. Profil guru/dosen (pendidik) yang demokratis tidak bisa terwujud dengan sendirinya tetapi membutuhkan proses pembelajaran"

\section{Hambatan Penanaman Sikap Nasionalisme}

Dalam penanaman sikap nasionalisme terdapat beberapa hambatan yang dapat mempengaruhi keberhasilan atau kegagalan suatu proses penanaman 
sikap nasionalisme. Perbedaan sikap atau perilaku setiap manusia berbeda-beda, hal ini dapat dipengaruhi oleh dirinya sendiri maupun motivasi yang berasal dari luar dirinya.

\section{Faktor Internal yang Berasal Dari Dalam Diri Peserta Didik}

Faktor internal adalah faktorfaktor yang berasal dari dalam diri individu atau dari dalam diri peserta didik. Semangat nasionalisme peserta didik (siswa/mahasiswa) menunjukkan kecenderungan rasa kebangsaan (nasionalisme) itu berarti bahwa siswa/mahasiswa berada pada tingkat sedang kerendah terlihat dalam beberapa kegiatan dan sikap peserta didik seperti upacara bendera setiap hari senin, penghargaan peserta didik tentang hasil produksi dalam negeri, dan sikap peserta didik terhadap budaya daerah setempat.

Menurut hemat penulis bahwa daya tangkap peserta didik terhadap materi pelajaran $\mathrm{PKn}$ ataupun Mata kuliah Pancasila/PKn di Perguruan Tinggi yang dapat menumbuhkan semangat nasionalisme dianggap menjenuhkan sehingga karakter dan motivasi peserta didik terhadap nasionalismenya mengalami

kemorosotan/kurang

\section{Faktor Eksternal yang Berasal dari Lingkungan Institusi Pendidikan}

Faktor eksternal adalah faktorfaktor dari luar diri individu atau dari luar diri peserta didik. Sekolah/Pendidikan Tinggi kurang menyediakan kegiatan yang mendukung semangat nasionalisme sehingga membuat pemahaman siswa tentang nasionalisme kurang.

Dari hasil wawancara menurut ibu Mardiah Umar, S.Pd selaku guru PKn (SMPN 2 Bangkala) mengatakan bahwa: "Hambatan yang dihadapi dalam penanaman sikap nasionalisme yaitu karena adanya faktor lingkungan yang tidak mendukung."(wawancara dilakukan pada tanggal 25 Juni $2019^{11}$ ).

Faktor penghambat lain dalam rangka penanaman sikap nasionalisme siswa disekolah SMP Negeri 2 Bangkala adalah cara penyampaian materi pembelajaran oleh guru yang hanya melalui penggunaan cerita saja. Padahal, kegiatan seperti diskusi kelompok dan sosiodrama dapat dijadikan cara untuk menyampaikan materi sekaligus menanamkan sikap nasionalisme siswa.

Selain itu, faktor waktu serta kesenjangan antara lingkungan keluarga dan masyarakat diluar sekolah juga sangat berpengaruh terhadap penanaman sikap nasionalisme siswa.

Hal tersebut disampaikan oleh guru Sahabuddin, S.Pd (SMP Negeri 2 Tarowang) yaitu: "Bahwa faktor yang paling berpengaruh terhadap sikap nasionalisme yang ditunjukkan siswa adalah lingkungan masyarakat. Ketika siswa berada di ruang kelas dan diberikan materi cinta tanah air oleh guru, siswa sangat berantusias. Akan tetapi, ketika siswa kembali ke masyarakat bisa saja berubah. Misalnya, ketika siswa di sekolah menyanyikan lagu nasional namun ketika pulang siswa beralih menyanyikan lagu-lagu yang sudah beredar didalam masyarakat.“ (wawancara dilakukan pada tanggal 26 Juni 2019 ${ }^{12}$ )

Pernyataan yang disampaikan guru sejalan dengan Sabaruddin, S.Pd. (SMP Negeri 5 Turatea) bahwa: "Keluarga dan lingkungan pergaulan siswa di masyarakat sangat berpengaruh. Sebab, kondisi masyarakat di daerah tersebut, walaupun di desa dan jauh dari kota, tetapi situasinya sangat melebihi

\footnotetext{
${ }^{12}$ Wawancara 26 Juni 2019
} 
kota".(wanwancara dilakukan pada tanggal 30 Juli 2019 ${ }^{13}$ )

Bapak Drs. Nur Alam, M. Si. (Kepala Dinas Pendidikan Kabupaten Jeneponto) juga menambahkan bahwa: "Penanaman sikap nasionalisme membutuhkan proses yang panjang untuk membentuknya sehingga membutuhkan kesabaran dalam pembentukannya, mengingat situasi sosial masyarakat Jeneponto terkhusus daerah tempat tinggal siswa itu keras"(wawancara dilakukan pada tanggal 30 juli $2019^{14}$ )

\section{Upaya Yang Dilakukan Sekolah Dalam Meningkatkan Nasionalisme Siswa SMP Negeri di Jeneponto}

\begin{abstract}
Upaya adalah usaha atau ikhtiar yang dilakukan seseorang untuk mencapai suatu tujuan serta memecahkan persoalan. Berdasarkan hasil penelitian yang dilakukan di SMP Negeri di Kabupaten Jeneponto, upaya yang dilakukan sekolah dalam meningkatkan nasionalisme siswa yaitu pengaktifan organisasi siswa baik ekstrakurikuler maupun intra sekolah.
\end{abstract}

\section{Organisasi siswa intra sekolah (OSIS)}

Organisasi intra sekolah (OSIS) adalah suatu organisasi yang berada ditingkat sekolah di Indonesia yang dimulai dari sekolah menengah yaitu Sekolah Menengah Pertama (SMP) dan Sekolah Menengah Atas (SMA). OSIS dikelola oleh murid-murid terpilih untuk menjadi pengurus. Organisasi ini juga memiliki seorang pembimbing dari guru yang dipilih oleh pihak sekolah.

Anggota OSIS terdiri atas dua yaitu anggota aktif, dimana anggota yang terlibat langsung dalam kepengurusan sedangkan anggota pasif adalah seluruh siswa yang berada pada satu sekolah. Anggota OSIS juga memiliki hak untuk memilih calon pengurus yang akan bertanggungjawab di kepengurusan inti. Sejarah lahirnya osis sendiri dimulai sekitar tahun 1970 sampai dengan 1972, beberapa pimpinan organisasi yang sadar akan maksud dan tujuan belajar disekolah, ingin menghindari bahaya perpecahan karna pada saat itu organisasi selalu terkontaminasi dengan politik yang dapat memecah bela sehingga para siswa menjalan organisasi intra sekolah dengan mengikuti arahan dari pimpinan departemen pendidikan dan kebudayaan. Dasar hukum osis diantaranya: (a) Undang-undang No. 20 tahun 2003 tentang Sisdiknas. (b) Peraturan pemerintah No. 19 tahun 2005 tentang Standar Nasional Pendidikan. (c) Permendiknas Nomor 23 tahun 2006 tentang standar kompetensi lulusan. (d) Permendiknas nomor 19 tahun 2007 tentang standar pengelolaan. (e) Permendiknas nomor 39 tahun 2008 tentang pembinaan kesiswaan. (f) Buku panduan OSIS terbitan kemdiknas tahun 2011.

Deskripsi kerja osis dalam pembinaan keperibadian unggul, wawasan kebangsaan dan bela negara, antara lain: (a) Melaksanakan upacara bendera pada hari senin dan hari-hari besar nasional. (b) Menyanyikan lagulagu nasional (Mars dan Hymne). (c) Melaksanakan kegiatan kepramukaan. (d) Mengunjungi dan mempelajari tempattempat bernilai sejarah. (e) Mempelajari dan meneruskan nilai-nilai luhur, kepeloporan, dan semangat perjuangan para pahlawan. (f) Melaksanakan kegiatan bela negara. (g) Menjaga dan menghormati simbol-simbol dan lambang-lambang negara;

Berdasarkan hasil wawancara menurut bapak Nur Alam, M. Si. (Kepala

\footnotetext{
${ }^{13}$ Wanwancara 30 Juli $2019 \quad{ }^{14}$ Ibid
} 
Dinas Pendidikan Kabupaten Jeneponto) mengatakan bahwa: "Dalam pengambangan intra sekolah siswa telah dibekali dan dipantau untuk membentuk karakter siswa khususnya nasionalisme itu tercurah dalam program kerja osis yaitu : Pembinaan Ketakwaan terhadap Tuhan Yang Maha Esa, Pembinaan Kepribadian dan Budi Pekerti Luhur atau Akhlak Mulia, Pembinaan demokrasi, hak asasi manusia, pendidikan politik, lingkungan hidup, kepekaan dan toleransi sosial dalam konteks masyarakat plural, Pembinaan Kepribadian unggul, wawasan kebangsaan, dan bela negara."(wawancara dilakukan pada tanggal 1 agustus $2019^{15}$ )

Hal senada diungkapkan oleh bapak Ali Akbar Kasmad (Guru SMP Negeri 5 Tamalatea yaitu: "Penanaman sikap nasionalisme siswa kami kembangkan dalam program kerja OSIS yang sedikitnya mulai dilaksanakan siswa seperti pelaksanaan upacara setiap hari senin, penghafalan lagu nasional, menghormati lambang atau simbol negara serta menghormati nilai leluhur".( wawancara dilakukan pada tanggal 1 agustus $2019^{16}$ )

Sedangkan menurut bapak Syamsuddin Guru di SMP negeri 1 Arungkeke yaitu: "Upaya yang dilakukan dalam meningkatkan sikap nasionalisme yaitu mengaktifkan kembali intra dan ekstrakurikuler sekolah".( wawancara dilakukan pada tanggal 30 juli 2019 ${ }^{17}$ )

Sedangkan menurut Ayuni Rasyid selaku ketua osis (siswa SMP Negeri 2 Bangkala) memberikan ungkapan sebagai berikut: "Kami dalam kepengurusan telah berusaha semaksimal mungkin untuk melaksanakan program kerja termasuk salah satunya Pembinaan Kepribadian unggul, wawasan kebangsaan, dan bela negara, teman- teman dikepengurusan juga terlihat antusias dalam pelaksanaan program kerja meski masih ada yang bersikap tidak perduli."( wawancara dilakukan pada tanggal 28 juli $2019^{18}$ )

\section{PENUTUP}

Berdasarkan hasil pembahasan menunjukkan bahwa: (1) Proses pembinaan semangat nasionalisme perlu dilakukan supaya identitas siswa sebagai warga negara Indonesia tidak menghilang yaitu dengan mengintegrasikan prinsip yang terkandung dalam nasionalisme seperti (a) prinsip kebersamaan yang menuntut setiap warga negara untuk menempatkan kepentingan bangsa dan negara di atas kepentingan pribadi dan golongan, (b) prinsip persatuan dan kesatuan yaitu warga negara harus mampu mengesampingkan kepentingan pribadi atau golongan yang dapat menimbulkan perpecahan dan anarkis (merusak), (c) prinsip demokrasi/demokratis memandang bahwa setiap warga negara mempunyai kedudukan, hak, dan kewajiban yang sama. (2) Penanaman sikap nasionalisme terdapat beberapa hambatan yang dapat mempengaruhi keberhasilan atau kegagalan suatu proses penanaman sikap nasionalisme. Perbedaan sikap atau perilaku setiap manusia berbeda-beda, hal ini dapat dipengaruhi oleh dirinya sendiri maupun motivasi yang berasal dari luar dirinya, seperti (a) Faktor Internal yang Berasal Dari Dalam Diri Peserta Didik, (b) Faktor Eksternal yang Berasal dari Lingkungan Institusi Pendidikan. (3) Upaya yang dilakukan sekolah dalam meningkatkan nasionalisme siswa yaitu pengaktifan organisasi siswa baik ekstrakurikuler maupun intra sekolah.

\footnotetext{
${ }^{17}$ Wawancara 30 Juli 2019

${ }^{18}$ Wawancara 28 Juli 2019
}

${ }^{15}$ Wawancara 1 Agustus 2019
${ }^{16}$ Wawancara 1 Agustus 2019 


\section{DAFTAR PUSTAKA}

Anas Muhammad, 2007. "Pengantar Psikologi Sosial”. Makassar, Badan penerbit UNM

Budiyono, Kabul. 2007. "Nilai-Nilai Kepribadian dan Kejuangan Bangsa Indonesia". Bandung: Alfabeta

Gatara FH Asep Sahid \& Sofhian, Subhan. 2012. "Pendidikan Pancasila (Civic Education)". Fokusmedia.

Madjid, N. 2004. "Indonesia Kita" Jakarta. PT Gramedia Pustaka Umum.

M Daryono, dkk .1997."Pengantar Pendidikan Pancasila dan Kewarganegaraan" Jakarta Timur: Rineka Cipta

Rahayu, Ani Sri. 2014 .Pendidikan Pancasila \& Kewarganegaraan (PPKn)" Jakarta. Rineka Cipta.

Saksono, Gatut. 2007. "Pancasila Soekarno”. Yogyakarta: Urna Cipta Media Jaya.PT Raja Grafindo Persada

Syarbaini, Syahrial dkk. 2006. "Membangun Karakter dan Kepribadian melalui Pendidikan
Kewarganegaraan”.

Yogyakarta: Graha Ilmu.

Syarbaini, Syahrial M.A. 2011. "Pendidikan Pancasila (Implementasi Nilai-Nilai Karakter Bangsa) Diperguruan Tinggi". Ghalia Indonesia.

Pureklolon, Tomas Tokan. 2017 "Nasionalisme dalam supremasi perpolitikan Negara". Jakarta: PT Gramedia Pustaka Utama.

Wandhi Pratama Putra Sisman \& Rauf, Ruslan. 2016."Pendidikan Kewarganegaraan Bingkai NKRI'. Jakarta, Mitra Wacana Media.

Yudohusodo, Siswono dkk. 1994." Nasionalisme Indonesia Dalam Era

Globalisasi”. Yogyakarta: Yayasan Widya Patria.

Undang-Undang Dasar Negara Republik Indonesia Tahun 1945 pasal 27 ayat 3 .

Undang-Undang Nomor 3 Tahun 2002 tentang Pertahanan Negara pasal 9 ayat $1,2 \& 3$.

http://belajarpendidikanpkn.blogspot.co.i d/2017/07/prinsip-prinsip yang terkandung dalam nasionalisme diakses tanggal 20 Maret Jam 12 WIB 2019. 